\title{
Investments in Shares of Islamic Studies Thinking Jasser Auda
}

\author{
Mutawalli Mursyid Al-basyar ${ }^{1 *}$, Indah Yuliana² \\ 1,2Pascasarjana Ekonomi Syariah, Universitas Islam Negeri Maulana Malik Ibrahim, Malang-Indonesia
}

\section{A R T I C L E I N F O}

\section{Article history:}

Received 9 January 2020

Received in revised form 7 June 2020

Accepted 9 June 2020

Available online 29 June 2020

\section{Kata Kunci:}

Saham Syariah; Maqashid

Syariah; Jasser Auda

Keywords:

Shares Sharia; Islamic maqashid; Jasser Auda

\begin{abstract}
A B S T R A K
Pada sebagian umat Islam ada yang beranggapan bahwa investasi saham syariah itu tidak diperbolehkan (diharamkan) karena tidak sesuai dengan syari'at Islam. Namuan mayoritas umat islam beranggapan bahwa investasi saham syariah merupakan salah satu bentuk kegiatan muamalah yang telah memenuhi prinsip syari'ah. Tujuan dari penelitian ini adalah untuk mengetahui praktik investasi saham syariah pada Pasar Modal Syariah ditinjau dari perspektif Maqashid al- Syariah pandangan Jasser Auda. Jenis penelitian yang digunakan dalam penelitian ini adalah jenis penelitian kualitatif normative, dengan jenis pendekatan studi literature (penelitian kepustakaan) dengan sumber data yaitu, data sekunder yang diperoleh dari penelitian-penelitian terdahulu, dan sumber referensi lainnya. Pada dasarnya jual beli saham syari'ah berlangsung dengan senantiasa lebih memperhatikan hak-hak dari masing-masing investor yang melakukan investasi. Lebih jauh investasi saham syariah jika diamati dari aspek maqashid syariah perspektif jasser auda yaitu Maqashid Ammah, Maqashid Khassah, dan Maqashid Juz'iyyah dapat dikatakan bahwa pada taraf ini dalam prakteknya, investasi saham syariah telah memenuhi ketiga kategori Maqasid asy-Syari'ah tersebut.
\end{abstract}

A B S T R A C T

At some Muslims there who think that the investment of Islamic stocks is not allowed (forbidden) because it does not conform to the Islamic shariah. But the majority of Muslims believe that sharia stock investing is one form of activity muamalah have to meet the principles of Shariah. The purpose of this study was to determine the investment practices of Islamic stocks on Islamic Capital Markets viewed from the perspective of Maqashid Sharia Jasser Auda view. This type of research is used in this research is qualitative normative research, with the kind of approach to the study of literature (literature research) with the source of data is secondary data obtained from previous studies, and other reference sources. Basically, buying and selling shares of Shariah in progress by continuing to pay more attention to the rights of the individual investors who make investments. Further investment of Islamic stocks if observed from the aspect of sharia perspective maqashid Jasser Auda is Maqashid Ammah, Maqashid Khassah, dan Maqashid Juz'iyyah can be said that at this stage in practice, sharia stock investment has fulfilled the three categories Maqasid the ash -Shariah.

\footnotetext{
${ }^{*}$ Corresponding author.

E-mail : cicitmursyid@gmail.com (Mutawalli Mursyid Al-basyar)
} 


\section{Introduction}

Investment is one form commitment to the number of funds or other resources were committed with intent to obtain a benefit and the benefit in the future. This investment is a form of muamalah highly recommended in Islam, even essentially already described in the Koran (Qur'an, al-Baqarah [2]: 261; QS. Al-Nisa [4]: 9; QS. Yusuf [12]: 46-49; QS. Luqman [31]: 34 and QS. al-Hashr [59]: 18) and additionally reinforced by the sunnah of prophet Muhammad $n$, where he was 21 centuries ago was a partner with investors while businesses. (Sakinah, 2014; Elif Pardiansyah, 2017). Basically, Islam strongly encourages people to do investment, so this was the background for an order to pay zakat to those who have no productive assets (idle assets). But on the contrary if the assets are managed in a productive not subject to the obligation of zakat. Which new charity will be collected from the results that have been obtained through the investment (Mardhiyah Hayati, 2016).

Investment in Islamic constituted by intention in accordance with the teachings of Islam as well. Investment Islamic teachings also recognize their profits, as well as investments in view of the capitalist economy. Investing in Islam does not make profit the only goal in muamalah. In Islam the most important goal in investing is maslahah. This maslahah obtained in the interests of the good of human life as a servant of Allahk, Both with regard to their earthly life and the lives of his hereafter. In order to obtain the positive aspects predominate, then the Islamic investments are made must be on the basis of goodwill and management in accordance with the teachings of Islamic law. Investment in Islamic perspekti should emphasize the context mudaraba and Musharaka. Both sides should commit sharing profits and losses in proportion to the amount of the contribution and the negotiation of mutually agreed (Musleh, 2016). The fact that happened today that often investments that offer a fantastic advantage with mild effort, be regarded as normal investments and may do even that has been prevailing in the society. However, if examined from financially good side,

The shape of today's modern investment is an investment in shares. At the release of the Islamic economic system of values usury, gharar and maysir, was a gift of Allahkwhich often fail to understand when economic activity. In this case as the case of buying and selling stocks, which tend to give priority to profit in its implementation. Stock itself is one part of the investment in the form of financial assets which are currently being developed in Indonesia (Ainun Mardiah, 2015). While Islamic stocks alone, according to the National Sharia Council (DSN) is defined as a form of proof of ownership of some assets of a company that meets the criteria of sharia and not including the shares have privileges (Yuliana, 2010).

Currently it has formed a stock classified as Islamic stocks. Which of these stocks issued by listed companies and companies that form the basis of its business is in compliance with the provisions of Islamic law. Islamic stocks can be said as the shares traded in the Islamic capital market. Basically the same as the share of Islamic stocks in the conventional capital market. Only difference of shares traded in the Islamic capital market must come from issuers that meet the criteria of sharia. Besides the most fundamental difference with the Islamic stocks on the stock market, namely conventional capital, shares of sharia in practice should not contain usurious transactions, transactions gharar, as well as issuers and companies belonging to the Islamic capital market does not move in the sector has been forbidden by shariah'ah (Amalia Nuril Hidayati, 2017). Thus, if the shares are securities that represent equity into a company. So in Islamic principles, capital investments made in companies that do not violate Islamic principles, such as the field of gambling, usury, producing goods that are forbidden such as beer, and others.

In the texts if we examine further about the legality of Islamic stocks investments, then we would be difficult to find texts that clearly explains about Prohibition is allowed or stock investments sharia. Therefore, by introducing a top view of halal Islamic stock investment. Which in the majority of Muslims there who think that the investment of Islamic stocks was not yet fully apply the principles of Islam. However, the majority of Muslims think that investment in Islamic stocks is a form of muamalah activities. Based on the legal rules of origin, the form of muamalah activities is mubah (allowed). This shows that when an activity that muamalah emerging and unknown in the old days in the tenets of Islam.

With the issuance of fatwa contemporary scholars concerning the practice of buying and selling shares of sharia further strengthen the legality of the practice of buying and selling shares muamalah ie. One of them contained in the collection of the National Sharia Board fatwa Saudi Arabia Syakh Abdul Aziz ibnu Abdillah ibnu Baz purchase volumes 13 chapters fatwa 20-321 pages 4016 and 5149 the number of share purchase law. Likewise, based on Fatwa No. 80 / DSNMUI / III / 2011 concerning the application of Islamic principles in the mechanisms of equity securities trading on the regular market exchange. This is the underlying IDX Indonesia establish Sharia Stock Index (ISSI) with the intent to be a reference and source of information for investors to invest in shares of Sharia. So that with the establishment of this ISSI can at least be used as a tool for BEI in giving an overview to the investors on the performance of all stocks listed 
sharia. However, the big question is whether stocks have met the criteria of sharia being taught in Islam. In Islamic economics does not only look at aspects of the lawful and unlawful per se, but that is not less important also to know is the extent of his involvement in the welfare of the community. This is the purpose of the maqashid sharia.

Jasser Auda is one of the contemporary scholars are also elicits maqashid concept of sharia, explaining that mqashid in Islamic law is at the core of the whole methodology of Ijtihad proposal bai of linguistic and rational aspects. The realization of maqashid in the legal system of Islam from the perspective of the system, the very openness, realism, transparency and flexibility. So that the validity of ijtihad or the validity of a law should be determined by the level of realization of the maqasid sharia. Therefore, the validity of ijtihad or the validity of a law should be determined by the level of realization of Islamic Maqasid he did. Thus, the result of ijtihad or legal conclusion reached Maqasid should be legalized. In conclusion, the process of ijtihad becomes effective, a process of realizing Maqasid in Islamic law.

\section{Literature and Hypothesis}

\section{Concepts and Principles of Islamic Stock Investment}

Shares are equity securities to the company's evidence and the evidence of the participation of shareholders entitled to receive part of the business results of the company (Sutedi, 2011). The concept of equity with the right part of this effort the result is a concept that is not contrary to Islamic principles. Islamic principles recognize the concept of Sharia Shares Investment as Musharaka or syirkah activities (Elif Pardiansyah, 2017) (Musleh, 2016). Based on the description above, it can be concluded that the concept of Islamic stocks is a form of muamalah that does not conflict with Islamic principles. In addition, shares issued by issuers and companies are not all classified as sharia shares. Therefore, the principles of sharia equity for investors, shall be made on issuers and companies that do not conflict with Islamic principles. The criteria for issuers and companies to conduct that is contrary to the sharia from the aspect of the object and the way (process) among listed companies and companies whose activities contain elements of usury, maysir, tadlis, gharar, darar, Ghabn, talaqqi rukban, taghrir, risywah, immoral, and unjust,

Moreover, it is equally important to note is the knowledge of the investment will be related sciences, it deepened that investment activity we do is worth worship, get inner satisfaction and blessing the world and hereafter (Sakinah, 2014). The effort can be reached by an old investors and prospective investors in order to select issuers and companies that meet the requirements of Islamic stocks or not. Can be seen with syariah screening methods, namely, first look at the business being operated, whether it is a process, and the product goods; second, analyzing the ratio of non-halal income and interest-based debt ratio to total assets (Elif Pardiansyah, 2017).

\section{Shares Investment in the view of Islamic law Sharia}

Islamic investment basically included in Islamic finance where all the applicable provisions in it using a system whose implementation is based on the laws and principles of sharia. As one form of Islamic investment products is buying and selling shares of sharia. However this is in some communities there are those who think that the form muamalah with investment of Islamic stocks is a violation of sharia. Because it contains elements of gambling and speculation that conflict with Islamic law. If examined in depth Based on the literature of Islam began classical era to the present, it will not be found penjeleasan clearly about the terminology and explanations of equity investment on the capital market. But as an economic activity, muamalah activities can be categorized as the sale and purchase of activity (Al-Bai '). So with that, to determine whether the investment activities of Islamic stocks can be classified as a form of muamalah permissible or not according to Islamic law. It is necessary to know beforehand the things banned / proscribed by Islamic law in relation to the buying and selling activities.

Islamic stocks can also be said as one form of products traded on the Islamic capital market. Therefore, if we compare between conventional shares and Islamic stocks there is no significant difference. It's just a striking difference between the two, namely, shares traded in the Islamic capital market must come from issuers and companies that meet the criteria and principles of sharia (Syariah Compliance). So if the shares are securities that represent equity participation in a company, then in the sharia principle capital participation is carried out on companies that do not violate sharia principles, such as gambling, usury, and producing prohibited goods. The share capital investment can be made based on the Musyarakah and Mudharabah agreements. The musyarakah contract is generally applied to companies that are private, while mudharabah contracts are generally conducted on shares of public companies (Soemitra, 2009). 
In practice, Islamic stocks provide benefits based on the ratio of shares invested in an issuer or company. But not only that, investors must also be prepared to share in the losses suffered by the issuer or company. Based on the results of studies conducted by scholars and economists, a decree No. 65/1/7 alMajma 'al-Islami was issued, Jeddah (Husein, 2004). Namely about Islamic stocks including First: because the legal origin of Muamalah is halal, then the establishment of a company with shares that have a purpose and activities that are permitted is halal. Second: there is no dispute at all about the prohibition of participating in investing in companies whose main purpose is haram. Like doing muamalah with usury or producing illicit goods and trading it. Third: the law of origin is involved in placing shares in companies that sometimes mingled with illicit things like, usury and others even though the main activity is permitted is haram. In this case contemporary scholars of fiqh experts also agree that it is forbidden to invest in the stock market in the capital market in an issuer or a company engaged in illicit business. Such as companies engaged in the production of liquor, business using pork, conventional financial services such as banks and insurance, and the entertainment industry, such as casinos, gambling, pornographic media, and so on. The propositions that forbid the sale and purchase of company shares like this are all the propositions that forbid all these activities.

\section{Maqhasid Shariah perspectives Jasser Auda}

Shari'ah Maqasid theory used in this research is the theory of Shari'ah Maqasid triggered by Jaseer $A u d a$, one of the leading experts in the field of Maqasid Shari'ah. Jasser Auda use Sharia as a base the base Maqasid reject the philosophy of thinking by using a systems approach as a method of thinking and knives analysis. A new approach that has never been thought to be used in the discussion of Islamic law and Usul al-Fiqh. There are six system features an optimized Jasser Auda as a knife analysis, the dimensions of cognition of religious thinking (cognition), comprehensiveness (wholeness), transparency (openness), hierarchical thinking interplay (interrelated hierarchy), think religious involving various dimensions (multidimensionality) and purposiveness (purposefullness). Until the end, realization of Maqasid that is the level of success of ijtihad. So that Islamic law proved to have the capacity to make a real change in the lives of Muslims (Auda, 2015).

According to Auda, that realization is the basis maqasid important and fundamental to the Islamic legal system. Digging maqasid must be returned to the main text (Qur'an and hadith), not the opinions or thoughts faqih. Therefore, the embodiment objectives (maqasid) a measure of the validity of each of ijtihad, without reference to the tendency or certain schools. Purposes of establishing Islamic law must be returned to the benefit of society who are around Jasser Auda Maqasid asserted that Islamic law is the core objective of the entire methodology of ijtihad linguistic and rational proposal. Furthermore, the realization Maqasid, from the standpoint of the system, maintains openness, reform, realism and flexibility within the Islamic legal system. Therefore, ijtihad validity or the validity of a law should be determined by the level of realization of Islamic Maqasid he did. Thus, the result of ijtihad or legal conclusion reached Maqasid should be legalized. In conclusion, the process of ijtihad becomes, effectively, a process of realizing Maqasid in Islamic law (Auda, 2008).

Jasser tried Maqasid hierarchy split into three categories, namely: First; Maqasid al-'Ammah (General Maqasid) is Maqasid which includes all maslahahs that are found in tasyri' behavior which are universal such as justice, equality, tolerance, convenience, including aspects of Dharuriyyat in Classical Maqasid. Second; Maqasid Khassah (Specific Maqasid) that is associated with maslahah Maqasid that exist in a particular issue, for example, should not be hurt women within the scope of the family, and not being allowed cheat in trade in any way. Third; Maqasid Juz'iyyah (parcial Maqasid) that Maqasid the very heart of a legal event. Maslahah is also called wisdom or secret. The third category of maqasid ash-shari'ah should be viewed holistically, not discrete and hierarchical as in the theory of classical maqasid. Maqasid unity is entirely to be seen in the spectrum or broader dimension. This is the entrance to innovate in response to context own problems of contemporary times (Faisol, 2012).

\section{Method}

This type of approach in this study is a literature study approach (research literature) with the source of data is secondary data obtained from previous studies, and other reference sources. Literature research is research whose findings are obtained by finding data from various literature and references relating to the subject matter discussed. Therefore, research on Stock Investment Perspective Maqasid Sharia in Islamic Thought Jasser Auda in this study using a document review and trend analysis. This type of research used in this research is qualitative research normative, ie, as the means used in legal 
research conducted by examining the existing library materials (Soerjono Soekanto and Sri Mamudji, 2009).

The data collection technique is the most strategic step in the research, because the main goal of the study is to get the data. In this study, researchers conducted a data collection techniques with a review of the literature conducted to look for concepts that have relevance to the topic of discussion in this study. Through the study of books, journals, magazines, as well as expert opinions indirectly, which will then be analyzed in depth. In addition, this research using descriptive analysis techniques, the analysis by exposing the data that has been collected and systematically arranged. The source of the data used as reinforcement in this study were obtained from several literature, documents and information about some of the findings of various books, journals and the results of previous studies. But before that the document had been through the stages of analysis of various data or the validity of the source of much studied by the researchers, as well as analyzed the facts are objective look at investment in Perspective Maqasid al-Sharia is growing in Indonesia.

\section{Result and Discussion}

\section{Stock Investment Sharia Legal Basis}

If we examine the literature of both classical and modern, at the time of the Rasulullah $n$, and the companions of the activities of Islamic stocks investment muamalah undeveloped as it is today. At that time the only known muamalah activity of buying and selling as seen on the markets in the current era. Proof of ownership by a company at that time have not been done in the form of stock like at this point, but only limited recognition of ownership (Syirkah). Evidence kepemimilikan or selling on an asset at the time of the Rasulullah $\mathrm{n}$ and friends, only through the mechanism of buying and selling ordinary and not through the intial public offering by making stock as an instrument. At that time it was only an ordinary rill market to exchange goods with money (buying and selling) and the exchange of goods for goods or barter (Nurul Huda and Mustafa Edwin Nasution, 2008).

The propositions of the Qur'an and the Hadith that serve as references for stock investment allegations as explained below are the arguments used as the basis for the issuance of the National Sharia Council of the Indonesian Ulama Council (DSN-MUI) No: 40 / DSNMUI / X2003, about the legality capital markets and the General Guidelines for the Application of Syriah capital market.

Al-Qur'an

"... and God justifies the purchase and forbids usury ..."(Qur'an, al-Baqarah [2]: 275).

$$
\text { وَأَحَلَّ المَّهُ الْبَيْعَ وَحَرَّمَ الرِّبَا }
$$

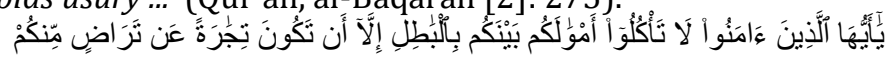

"O ye who believe, do not eat each other neighbor's property by way of vanity, except by way of commerce that goes with the same love-love between you."(QS. An-Nisa [4]: 29).

"O you who believe! Fill akadakad it ... "(QS. Al-Ma'idah [5]: 1).

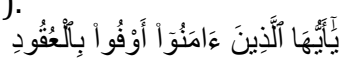

From the proposition above we can conclude first, the argument that first explain about the permissibility of muamalah form of buying and selling. So it can be said that all forms of muamalah done with the intent and purpose in accordance with sharia law including, but not contain elements of usury makal it is lawful to do. Departing from this that the investment activity of Islamic stocks on a issuers and companies that meet Islamic principles may or lawful to do.

Hadits

- $\quad$ "... illicit gains of a risk that is not covered, and is not kosher (do) not selling something that is in you" (Reported by al-Khomsah of Amr bin Shu'aib)

- "Not to be selling something until you have it" (Bayhaqi of Hukaim bin Hizam)

- "Prophet Muhammad forbade the sale and purchase containing gharar" (Muslim, Tirmidhi, Nasa'i, Abu Dawud and Ibn Majah from Abu Hurayrah).

The views Ulama

Contemporary jurists agree that classified the case are forbidden when trade the stock on the market of a company operating in the field unlawful. The arguments used them as reinforcing their opinion would be the prohibition of investment shares in a company that bastard is all the arguments which forbids any such activity. But besides that there is disagreement among them about the legal 
status of a company engaged in legitimate business, for example in the fields of transport, telecommunications, textile production, and so on. Below will be explained some of the opinions of contemporary scholars who consider that investing in shares is a thing that is permissible to do as long as it meets some requirements and does not conflict with the Shari'a.

- Syahatah and Fayyadh said, "Planting stock in a company like this is allowed in syar'i ... Evidence show skill are all arguments which show that activity is proper." (Syahatah and Fayyadh 2004, 17).

- The views of Ibn Qudaamah in al-Mughni juz 5/173 [Beirut: Dar al-Fikr, nd]: "If one of the two partners of association bought the portion of his union, the permissible because he bought the property of others."

- Opinion Dr. Wahbah al-Zuhaili in Al-Fiqh al-Islami wa Adillatuhu juz 3/1841: "muamalah with (carrying out transaction activities) legal shares are permissible, because the owner of the shares is a partner in the company in accordance with the shares owned."

\section{Shares Investment Sharia and Islamic Maqashid Jasser Auda}

From the results of the analysis conducted by researchers on sharia stock investment in the view of Maqashid sharia, namely at the level of al-maqāsid al-'ämmah, the researchers saw an improvement in the terminology of al-kulliyah al-khamsah. Which parts of al-kulliyah al-khamsah is in contemporary Maqasid concepts, such as: 1) hifdzul nasl of "protection descent" into the theory of family oriented and moral values in Islam; 2) hifdzul 'aqli of which are limited around the ban booze into the development of scientific thought, the journey studying, against taqlid mentality, and prevent mengelirnya experts abroad; 3) hifdzu din of punishment for leaving the right belief into freedom of belief; 4) hifdzul mall of protection money into economic development; 5) hifdzu nafs is more recommended towards the development of human resources.

One part of the al-kulliyah al-khamsah according to researchers who have direct coherence with the investment practices of Islamic stocks in particular are at the hifdzul mall (protection of property). Which in classical Maqasid explain that protection is the protection of personal property or individual, contemporary Maqasid further encourage the economic development needed by the public. Nonetheless, the four other theory can also have indirect continuity. If we observe that the share purchase prakttek sharia is the kind muamalah diperboleh in Islamic law because of the element of profit sharing (Syirkah) as applicable in Islamic economics. Any gains or corporate issuers, then investors will also get the same benefit or would obtain dividends from the issuer or the company, and vice versa when the company suffered a loss of investors also have to bear the losses. So with this is also expected to create a positive impact on the religious harmony (hifdzu din).

Furthermore, in practice sharia shares strongly emphasize the halal level of each issuer and company incorporated in JII, shares listed as sharia shares have been guaranteed halalness by the Indonesian Ulama Council (MUI), this is done in the framework of implementing moral values in Islamic teachings (hifdzul nasl). In addition, in this sharia stock investment activity investors are not only required to have large funds, but no less important is that investors are also required to be able to understand and analyze the work system of sharia stock investment itself (hifdzul 'aqli). Drawing this this case the investor can read books related to stock investments and investors may also subscribe to the capital market organized school oeh Indonesia Stock Exchange (BEI). Equally important is the presence of this Sayriah Shares Investment will increase in jobs for human resource development in the country (hifdzu nafs). Because these investments are giving money to companies that want to expand their business. If the companies are expanding their business will certainly require more manpower so that the business continues to run. So this is what makes this a very profitable Shares Investment Muslims. If the companies are expanding their business will certainly require more manpower so that the business continues to run. So this is what makes this a very profitable Shares Investment Muslims. If the companies are expanding their business will certainly require more manpower so that the business continues to run. So this is what makes this a very profitable Shares Investment Muslims.

By looking at the explanation above, we can know the meaning and purpose of Islamic stocks is a solution for Muslim investors who want to invest in shares that apply sharia principles, so that it can be said that al-maqāsid al-'āmmah has been achieved by this buying and selling practice. But in addition to aspects of development required in al-Maqasid al-ammah contemporary aspect of public protection also have contributed to the achievement of a Maqasid. Therefore, if we look at the legal aspects of Islam, the workings of the practice of buying and selling shares of sharia is performed in a single chamber (Bai 'alMusawamah) and carried out on an ongoing basis. By way of such work, the right of each investor who play a role in the practice of sharia stock purchase may be covered completely. Therefore Shari'ah share 
purchase is done by continuing to protect the rights of each party involved in the sale and purchase. So it can be said that the share purchase these Sharia compliant and meet the applicable requirements of Islamic law (Ahmad, 2018).

At the second level, namely al-Maqasid al-khāssah. In a more specific scope, this can be tough with the efforts made on July 3, 2000 the establishment of an institution called the Jakarta Islamic Index (JII) by the Indonesia Stock Exchange (IDX), which work directly with PT.Danareksa Investment Management by objectives to guide potential investors who want to invest in shariah. With the establishment of these institutions make it easier for investors determine which stocks can be used as containers sharia to invest in listed companies and companies in accordance with Islamic principles (Farida and Nur, 2013). On development, JII showed a positive trend over time, despite the existence of a group of stocks are still relatively new sharia.

While on the third level, namely al-Maqasid al-juz'iyyah, more focused on the partial section. When compared to how the stock trading between conventional and sharia would be very much different. The way of working applied in sharia stock investment practices is specifically to be incorporated in a Jakarta Islamic Index (JII) institution and the offer only occurs on the primary market. This is done so that there are no more elements of speculation and insider trading attitude, as occurred in the secondary market during this (Aziz, 2010). In addition, it is also done as a benchmark for the performance of the issuer and the company on the stock based on Shari'ah, so it can boost the confidence of investors invested in stock in an existing listed companies.

\section{Conclusions}

Thus from the results of the discussion above it can be concluded that, Islamic shares with conventional shares are basically no significant differences. It's just the difference between the two, namely, shares traded in the Islamic capital market must come from the issuer or company that meets the criteria of sharia (Shariah Compliance). The fulfillment of the rights of each party involved in it. Buying and selling sharia shares is done by always taking into account the rights of each party conducting the transaction. So, it can be concluded that this kind of buying and selling is appropriate and meets the requirements in accordance with Islamic Law. In addition, if we explore further the investment in sharia shares if observed from the aspect of sharia maqashid, perspective of jasser auda, namely al-maqāsid al-'āmmah, al-maqāsid al-khāssah, dan al-maqāsid al-juz'iyyah it can be said that at this level in practice, investment in Islamic stocks has fulfilled all three categories of Maqasid asy-Syari'ah.

\section{REFERENCES}

Abdullah, Boedi dan Ahmad Beni. (2014). Metode Penelitian Ekonomi Islam (Muamalah). Bandung: CV Pustaka Setia.

Adrian Sutedi. (2011). Good Corporate Governance. Jakarta: Sinar Grafika.

Auda, Jaseer. (2015). Membumikan Hukum Islan Melalui Maqasid Syariah. Terj. Rosidin dan Ali Abd elMun'im. Bandung: PT Mizan Pustaka.

Auda, Jasser. (2008). Membumikan Hukum Islam melalui Maqasid Syariah. Bandung: PT Mizan Pustaka.

Aziz, Abdul. (2010). Manajemen Invetasi Syari'ah. Bandung: Penerbit Alfabeta.

Faqih, Ahmad. (2018). Praktek Jual Beli Saham Syari'ah Perspektif Hukum Islam. Jurnal Iqtishad. Volume 5 , Nomor 1, Juni. 43-74

Fikriawan, Suad. (2018). Ivestasi dalam Perspektif Maqashid al-Syariah. Al-Mustashfa: Jurnal Penelitian Hukum Ekonomi Islam. Vol. 3, No. 1, Juni. 15.29

Hayati, Mardhiyah. (2016). Investasi Menurut Perspektif Ekonomi Islam. IKONOMIKA Jurnal Ekonomi dan Bisnis Islam. Volume 1, Nomor 1, Mei. 66-78

Hidayat, Amalia Nuril. (2017). Investasi: Analisis dan Relevansinya dengan Ekonomi Islam. Malia: Jurnal Ekonomi Islam. Volume 8, Nomor 2, Juni. 227-242

Huda, Nurul dan Mustafa Edwin Nasution. (2008). Investasi Pada Pasar Modal Syari'ah. Jakarta: Kencana,

Ibrahim, Ida Musdafia. (2013). Mekanisme dan Akad Transaksi Saham di Pasar Modal Syariah. e-Jurnal Ekonomi dan Hukum Islam. Jakarta: STIE YAI.

Mardiah, Ainun. (2015). Holding Period Saham Syariah Antara Investor dan Trader. Jurnal Perspektif Ekonomi Darussalam. Volume 1Nomor1, Maret. 44-54

Muhammad, Faisol. (2012). Pendekatan Sistem Jasser Auda terhadap Hukum Islam: ke arah fiqh PostPostmodernisme. Jurnal Kalam. Volume 6, Lampung. Volume 6, Nomor 1. 39-64 
Murtadho, Ali. (2014). Pensyari'ahan Pasar Modal Dalam Perspektif Maqashid Al-Syari'ah Fi Al-Iqtishad. Jurnal Economica. Volume V/Edisi 2/Oktober 2014. 1-16

Musleh. (2016). Investasi dalam Perspektif Islam. TAFAQQUH: Jurnal Hukum Ekonomi Syariah Dan Ahwal Syahsiyah. Volume: 1 Nomor: 1.1-16.

Pardiansyah, Elif. (2017). Investasi dalam Perspektif Ekonomi Islam: Pendekatan Teoritis dan Empiris. Economica: Jurnal Ekonomi Islam. Volume 8, Nomor 2 (2017): 337 - 373

Sakinah. (2014). INVESTASI DALAM ISLAM. Iqtishadia: Jurnal Ekonomi dan Perbankan Syariah. Volume. 1 No. 2 Desember. $248-262$

Soemitra, Andi. (2009). Bank dan Lembaga Keuangan Syariah. Jakarta: Kencana.

Soerjono, Soekanto dan Sri Mamudji. (2006). Penelitian Hukum Normatif. Jakarta: Raja Grafindo Persada

Syahatah, Husein \& Fayyadh, Athiyah. (2004). Bursa Efek: Tuntunan Islam dalam Transaksi di Pasar Modal (Adh-Dhawabit Al-Syar'iyah li At-Ta'amul fii Suuq Al-Awraq Al-Maliyah). Penerjemah A. Syakur. Surabaya: Pustaka Progressif.

Yuliana, Indah. (2010). Investasi Produk Keuangan Syariah. Malang: UIN-Maliki Press. 